\title{
PERANCANGAN SISTEM INFORMASI LEMBAGA KEMAHASISWAAN UNIVERSITAS KRISTEN SATYA WACANA SALATIGA
}

\author{
Rizki Apri Yustika Manurung ${ }^{1}$, Augie David Manuputty ${ }^{2}$ \\ ${ }^{1,2}$ Program Studi Sistem Informasi, Fakultas Teknologi Informasi, Universitas Kristen Satya Wacana
}

\section{Article Info:}

Dikirim: 13 April 2020

Direvisi: 28 Juni 2020

Diterima: 30 Juni 2020

Tersedia Online: 30 Juni 2020

Penulis Korespondensi: Rizki Apri Yustika Manurung Universitas Kristen Satya Wacana, Salatiga, Indonesia

Email: tikamnrng@gmail.com

\begin{abstract}
Abstrak: Lembaga Kemahasiswaan (LK) Univeristas Kristen Satya Wacana sebagai sebuah unit memiliki prosedur administratif yang terstruktur yang melibatkan berbagai unit terkait. Prosedur administratif tersebut berdampak terhadap adanya dokumen-dokumen yang dibutuhkan sebagai dasar melaksanakan program dan kegiatan. Prosedur administratif yang berjalan masih menggunakan berkas fisik dengan menggunakan kertas dan tinta printer. Akibatnya sering ditemukan masalah seperti pengelolaan proses dan dokumen yang memakan waktu, hilangnya dokumen, dan proses pendokumentasian yang belum terstruktur. Berdasarkan uraian tersebut sistem informasi yang terkomputerisasai dipandang dapat mendukung pengelolaan proses dan dokumen yang ada di LK. Metodologi pengumpulan data yang dipakai dalam penelitian ini menggunakan metode kualitatif. Penelitian ini menggunakan tahapan penelitian untuk mendekati masalah, melakukan analisa kemudian merancang sistem informasi. Perancangan sistem menggunakan pemodelan Flowchart (bagan alur kerja sistem), Data Flow Diagram (DFD), dan Entity Relationship Diagram (ERD).
\end{abstract}

Kata kunci: sistem informasi; lembaga kemahasiswaan; flowchart; DFD; ERD.

\begin{abstract}
Lembaga Kemahasiswaan (LK) Universitas Kristen Satya Wacana as a unit has a structured administrative procedure that involves a few related units. Administrative procedures have an impact on the documents needed as a base of carrying out programs and activities. The current administration procedure still uses physical files using paper and ink printer. Consequently many problems are often found such as require many times to manage process and document, document disappear, and unstructured documentation processes. Based on the description, the computerized information system is seen as able to support the management of the processes and documents in the LK. Method for collecting data used in this study uses qualitative methods. This study uses research stages to approach problems, analysis and then designing the information system. Design system used model flowchart (system workflow), Data Flow Diagram (DFD), and Entity Relationship Diagrams (ERD).
\end{abstract}

Keywords: information system; lembaga kemahasiswaan; flowchart; DFD; ERD. 


\section{PENDAHULUAN}

Komputerisasi sudah menjadi bagian yang penting bagi suatu instansi atau perusahaan dalam menjalankan proses bisnis, pasalnya penggunaan komputer dapat mempermudah pekerjaan, menghemat waktu dan tenaga. Dengan penggunaan komputer sebuah instansi atau perusahaan dapat mengelola informasi yang banyak dengan waktu yang singkat menjadi sebuah informasi yang dibutuhkan. Tidak heran komputerisasi menjadi pilihan tepat dalam memenuhi kebutuhan instansi atau perusahaan.

Universitas Kristen Satya Wacana (UKSW) sebagai instansi yang bergerak di bidang pendidikan memiliki visi yaitu membentuk mahasiswa menjadi creative minority yaitu pembentukan minoritas yang berdaya cipta bagi pembangunan dan pembaruan masyarakat dan negara Indonesia. Menurut Keputusan Rektor No. 270/Kep./Rek./8/2012 Tentang Pemberlakuan Skenario Pola Pembinaan Mahasiswa Universitas Kristen Satya Wacana, Lembaga Kemahasiswaan (LK) merupakan upaya-upaya terpadu dan kerja sama kelembagaan dari berbagai elemen organisasi di UKSW. Tujuan LK adalah upaya nyata dalam menerjemahkan dasar, visi dan misi UKSW dalam konteks kemahasiswaan dan bagi mahasiswa. LK UKSW dibagi menjadi dua level yaitu lembaga kemahasiswaan universitas (LKU) dan lembaga kemahasiswaan fakultas (LKF). Sebagai sebuah unit, LK memiliki prosedur administratif yang terstruktur dan melibatkan berbagai unit terkait di UKSW seperti Pembantu Rektor III Bagian Kemahasiswaan (PR III), Biro Akuntansi dan Keuangan (BAK), Biro Kemahasiswaan (Bikem), dan Koordinator Bidang Kemahasiswaan Fakultas (Koorbidkem).

Prosedur administratif tersebut disusun dan dilaksanakan sebagai bagian dari wujud pelaksanaan fungsi LK melalui adanya berbagai program dan penyelenggaraan kegiatan. Prosedur administratif yang dijalankan LK UKSW masih dilakukan secara manual berupa berkas fisik. Akibatnya sering muncul masalah seperti proses validasi dokumen yang memakan waktu karna dilakukan secara face to face, hilangnya dokumen penting, penumpukan dokumen di satu tempat tertentu, membutuhkan space yang banyak untuk menyimpan dokumen, minimnya tracking dokumen, kehilangan history dokumen.

Yoga Marsal Wamese (2018) melakukan penelitian yang bertujuan untuk membangun sistem informasi yang dapat diakses melalui web, sehingga informasi yang dikelola oleh panitia dan kontingen dapat bermanfaat bagi peserta kontingen dan masyarakat luar. Metode pengembangan sistem prototype, dengan tahapan pemodelan Data Flow Diagram (DFD), Entity Relationship Diagram (ERD), perancangan tabel dan perancangan antarmuka interface [1].

Tika Yesi Kristiani, dkk (2018) melakukan penelitian yang bertujuan untuk memudahkan proses pencatatan dan melihat informasi hasil kegiatan lomba mahasiswa universitas dengan metode pengembangan sistem yaitu Rapid Application Development (RAD) [2].

Mengacu pada penelitian terdahulu, maka akan dilakukan penelitian yang berjudul Perancangan Sistem Informasi Lembaga Kemahsiswaan Universitas Kristen Satya Wacana. Perbedaan antara penelitian terdahulu yang menjadi referensi dengan penelitian ini adalah penelitian ini berisi tentang perancangan sistem LK di UKSW yang dirancang sesuai dengan kebutuhan dari hasil wawancara. Sistem dirancang untuk memudahkan pengolaan proses dan dokumen yang meliputi program kerja, proposal kegiatan dan keuangan, laporan pertanggung jawaban (LPJ) kegiatan dan keuangan.

\section{METODOLOGI PENELITIAN}

Metodologi penelitian menggambarkan cara untuk mengumpulkan informasi yang diperlukan untuk penelitian. Secara umum dibagi menjadi 2 yaitu metode kualitatif dan metode kuantitatif. Metode yang digunakan dalam penelitian ini adalah kualitatif. Metode kualitatif menekankan pada aspek pemahaman secara mendalam terhadap suatu masalah. Alat pengumpulan data metode kualitatif berupa dokumen, catatan observasi, penjelasan, dan wawancara.

\subsection{Tahapan Penelitian}

Adapun tahapan penelitian yang dilakukan dalam penelitian ini dapat dilihat pada gambar 1. Tahapan penelitian berdasarkan gambar 1 dibagi menjadi 4 tahapan.

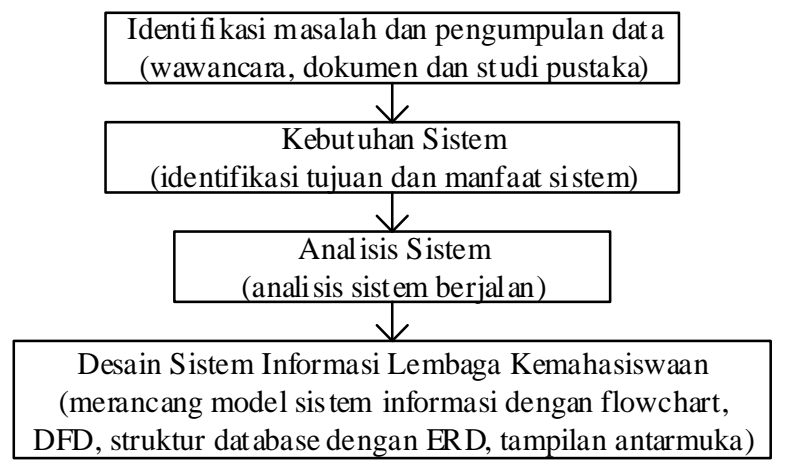

Gambar 1. Tahapan Penelitian 


\subsubsection{Identifikasi Masalah dan Pengumpulan Data}

Identifikasi masalah merupakan proses paling awal saat melakukan penelitian. Identifikasi masalah adalah kegiatan mengenali suatu masalah yang akan diteliti. Tujuan identifikasi masalah adalah memperoleh informasi yang dibutuhkan, merumuskan sebab dan akibat permasalahan penelitian. Identifikasi masalah menghasilkan rumusan masalah kemudian bagaimana masalah itu diukur dan dihubungkan dengan prosedur penelitian. Masalah yang telah didefenisikan siap diukur dengan melakukan pengumpulan data. Pengumpulan data dimaksud untuk mencari informasi-informasi yang mendukung kebutuhan penelitian. Pengumpuluan data dilakukan dengan wawacara, membaca dokumen dan studi pustaka. Wawancara dilakukan langsung dengan narasumber untuk mengetahui proses bisnis yang berjalan di LK UKSW dari awal hingga akhir. Dokumen diperlukan untuk mengetahui sistem tata kerja organisasi yang terdiri dari beberapa elemen yang diuraikan dengan jelas sehingga sistem yang akan dirancang sesuai dengan fungsi dan perannya dari seluruh unit di dalamnya. Studi pustaka dilakukan untuk mengumpulkan informasi yang relevan dengan penelitian untuk mendukung perancangan sistem dalam penelitian ini. Informasi dapat diperoleh dari buku ilmiah, karangan ilmiah, laporan penelitian maupun sumber tertulis baik elektronik maupun non-elektronik.

\subsubsection{Kebutuhan Sistem}

Tahapan analisis kebutuhan sistem diperlukan dalam proses perancangan sistem. Analisis kebutuhan sistem diperlukan untuk mengetahui kondisi atau kemampuan apa saja yang harus dimiliki oleh sistem untuk memenuhi kebutuhan pengguna. Analisis dilakukan dan disesuaikan berdasarkan pengumpulan data yang telah dilakukanakan. Analisis kebutuhan sistem mendukung tercapainya tujuan perancangan sistem. Tujuan dari perancangan sistem untuk memberikan gambaran utuh tentang permasalahan yang dihadapi, kemudian memberikan pandangan mengenai proses yang terjadi dalam LK UKSW. Sehingga sistem diharapkan diharapakan mendukung pengelolaan proses dan dokumen yang ada di LK.

\subsubsection{Analisis Sistem}

Setelah melakukan identifikasi masalah, pengumpulan informasi melalui wawancara, analisa dokumen, mencari informasi yang relevan dengan penelitian dalam bentuk cetak ataupun elektronik, dan analisis kebutuhan sistem, langkah selanjutnya adalah analisis sistem. Analisis sistem adalah tahapan penelitian pada sistem berjalan dengan tujuan untuk mengetahui segala permasalahan yang terjadi untuk memudahkan dalam menjalankan tahap selanjutnya yaitu tahap perancangan sistem. Hasil dari tahapan analisis sistem adalah menemukan kelemahan sistem berjalan. Berdasarkan kajian data, LK adalah sebuah unit, LK memiliki prosedur administratif yang terstruktur yang melibatkan berbagai unit terkait. Prosedur administratif tersebut disusun dan dilaksanakan sebagai bagian dari wujud pelaksanaan fungsi LK melalui adanya berbagai program dan penyelenggaraan kegiatan. Pelaksanaan prosedur administratif di LK berjalan sesuai dengan peraturan yang berlaku, baik di lingkungan LKU maupun LKF. Prosedur administratif tersebut berdampak terhadap adanya dokumen-dokumen yang dibutuhkan sebagai dasar melaksanakan program dan kegiatan yang telah dirancang. Dalam menjalankan prosedur administratif, LK berkoordinasi dan berkonsultasi dengan PR III, BAK, Bikem, dan Koorbidkem. Prosedur administratif terdiri meliputi program kerja, proposal kegiatan dan keuangan, LPJ kegiatan dan keuangan. Seluruh prosedur administratif yang sedang berjalan menggunakan berkas fisik dengan menggunakan kertas dan tinta printer cukup banyak, kemudian sering ditemukan masalah seperti proses validasi dokumen yang memakan waktu karna dilakukan secara face to face, hilangnya dokumen penting, penumpukan dokumen di satu tempat tertentu, membutuhkan space yang banyak untuk menyimpan dokumen, minimnya tracking dokumen, kehilangan history dokumen. Berdasarkan uraian tersebut penulis menawarkan sistem informasi sebagai solusi yang disesuaikan dengan kebutuhan pengguna.

\section{HASIL DAN PEMBAHASAN}

Pada bagian hasil dan pembahasan akan dibahas perancangan sistem berdasarkan kebutuhan pengguna yang merupakan tahapan selanjutnya dari tahapan penelitian. Sistem dirancang berdasarkan kebutuhan pengguna, hasil dari wawancara bersama narasumber. Narasumber dalam penelitian ini yaitu PR III, Koordinator Bikem dan Pimpinan LK UKSW. Selain itu membaca dokumen Mekanisme Kerja Eksekutif (MKE) untuk mendukung perancangan sistem sebagai dokumen yang menjelaskan bahwa kebutuhan akan adanya mekanisme yang mengatur fungsi dan peran dari seluruh unit yang ada di dalam LK . Studi pustaka juga dilakukan untuk menunjang akan kebutuhan informasi yang relevan dengan penelitian dengan membaca buku ilmiah, karangan ilmiah, laporan penelitian dan sumber-sumber tertulis baik tercetak ataupun elektronik. Sistem akan dirancang menggunakan flowchart untuk menggambarkan alur kerja sistem informasi, DFD menggambarkan aliran data yang ada di sistem informasi dan ERD sebagai model untuk mendesain database. PR III 
mengatakan "LK dalam posisi mereka sebagai rumah mahasiswa tidak punya proses dokumentasi setiap proses-proses yang ada seperti raker, rakor, proposal sampai pada pertanggungjawaban itu tidak ada, yang ada adalah suatu tumpukan besar itupun tidak lengkap. Padahal apa yang mereka lakukan ini berkenaan dengan progdi untuk akreditasi, berkenaan dengan laporan kinerja fakultas maupun kinerja universitas atau akreditasi universitas dan pengambilan keputusankeputusan baik di lembaga kemahasiswaan maupun progdi atau fakultas yang beriteraksi langsung dengan mahasiswa" (Andeka Rocky Tanaamah, wawancara, 5 Maret 2020).

Hasil wawancara menyatakan bahwa tidak ada pendokumentasi proses raker dan rakor, proposal dan LPJ. Raker (rapat kerja) adalah rapat untuk menyusun rencana program kerja dan rancangan anggaran selama 1 periode yang akan dibahas dalam Rakoor (rapat koordinasi) LK. Rakoor adalah rapat yang bertujuan untuk melakukan penetapan kebijakan program kerja dan anggaran pada masing-masing aras. Hasil Raker dan Rakoor yang dilakukan secara bertahap adalah program kerja. Berdasarkan pernyataan diatas maka sistem yang akan dirancang sesuai kebutuhan adalah pendokumentasian program kerja, pendokumentasian proposal kegiatan dan keuangan, dan pendokumentasian LPJ kegiatan dan keuangan.

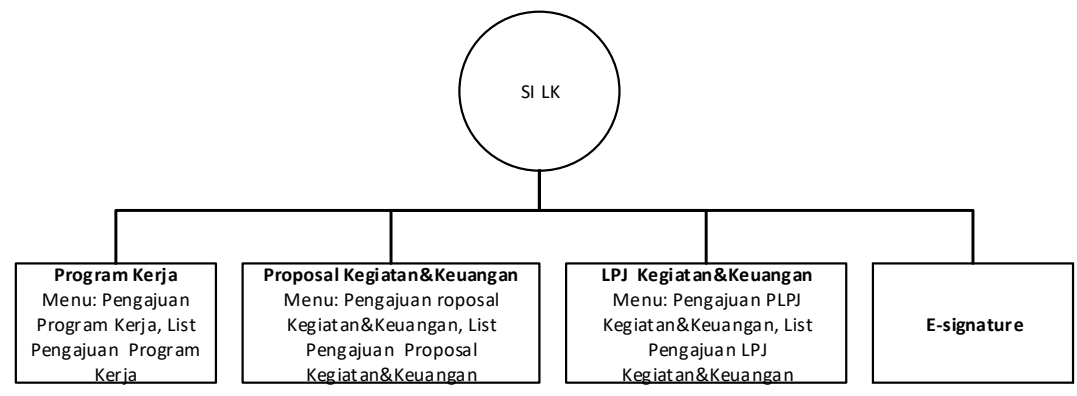

\section{Gambar 2. Gambaran Umum SI LK}

Pada gambar 2 menunjukan gambaran umum Sistem Informasi Lembaga Kemahasiswaan (SI LK) yang akan di rancang. SI LK akan melibatkan berbagai stakeholder sebagai user antara lain, LKU, LKF, Bikem, PR III, Koorbidkem, dan panitia atau satgas Ada 4 modul dalam perancangan sistem ini yaitu, modul program kerja terdapat menu pengajuan program kerja dan list pengajuan program kerja, modul proposal kegiatan dan keuangan terdapat menu pengajuan proposal kegiatan dan keuangan dan list pengajuan proposal kegiatan dan keuangan, modul lpj kegiatan dan keuangan terdapat menu pengajuan lpj kegiatan dan keuangan dan list pengajuan lpj kegiatan dan keuangan dan modul e-signature merupakan output hasil validasi oleh validator berupa e-signature. Pimpinan LK UKSW mengatakan "kalau kak masuk RM 2 disitu ada lemari, lemari itu didalamnya ada berkas, berkas nya itu cuma memorandum, lpj dan hasil rakor di beberapa tahun belakangan, itu pun ga lengkap misalnya ada hasil rakornya tapi ga ada lpjnya, lucu sekali ketika kita melakukan sesuatu dan tidak ada berkasnya" (Resny Adelina, wawancara, 9 Maret 2020)

Dari hasil wawancara, pimpinan LK menyatakan bahwa penyimpanan dokumen dilakukan dengan penumpukan berkasi fisik tidak terorganisir dengan baik. Oleh sebab itu sistem dirancang untuk mengelola proses pendokumentasian tidak memerlukan banyak tempat, mudah dideteksi dan mudah diakses, serta dokumentasi tidak hanya mencakup 2-3 tahun kebelakang. Tahapan pertama dari perancangan sistem ini menggunakan flowchart.

\subsection{Flowchart}

Flowchart adalah adalah bagan yang menunjukkan alir pekerjaan di dalam suatu program atau prosedur sistem secara struktrural yang dijelaskan melalui logika [3].

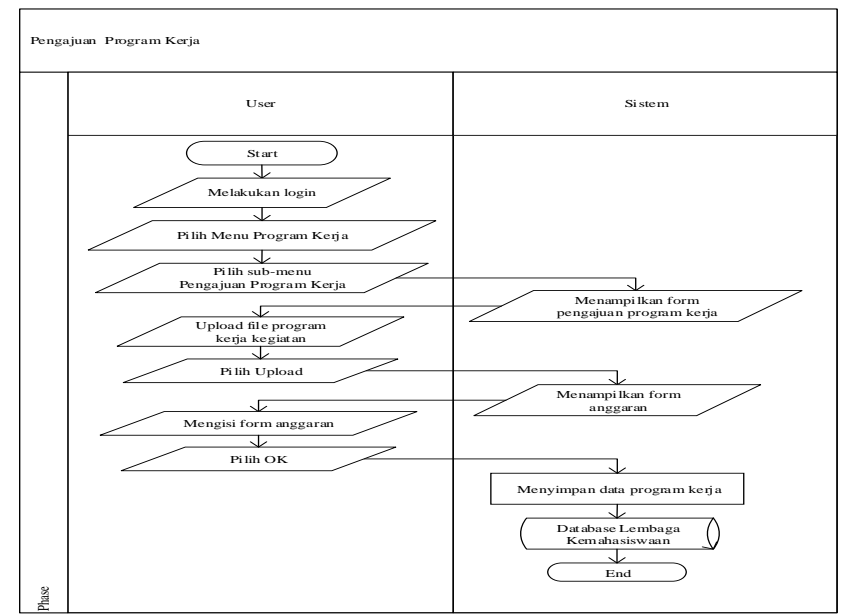

Gambar 3. Flowchart Pengajuan Program Kerja 
Gambar 3 menunjukan flowchart pengajuan program kerja, user login menggunakan username dan password untuk menuju ke halaman utama sistem. User terdiri dari fungsionaris LKF dan fungsionaris LKU. Menu ini digunakan user untuk upload file program kerja ke dalam sistem.

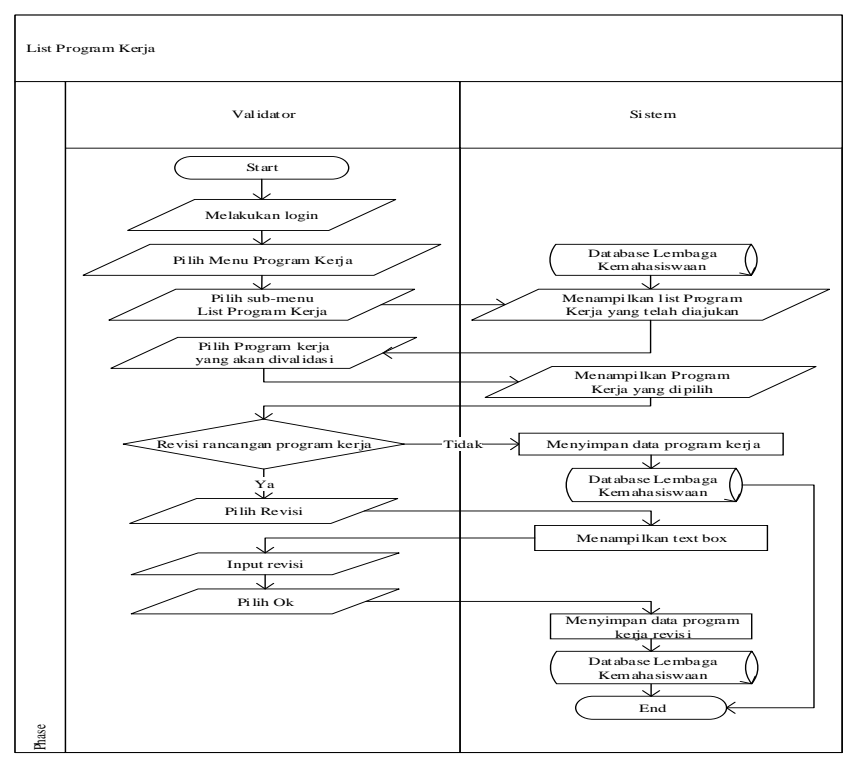

Gambar 4. Flowchart List Pengajuan Program Kerja

Gambar 4 menunjukan flowchart list pengajuan program kerja, validator harus login menggunakan username dan password untuk menuju ke halaman utama. Validator terdiri dari fungsionaris LKF, fungsionaris LKU, dan PR III. Validator memiliki peran untuk memvalidasi program kerja yang telah diajukan.

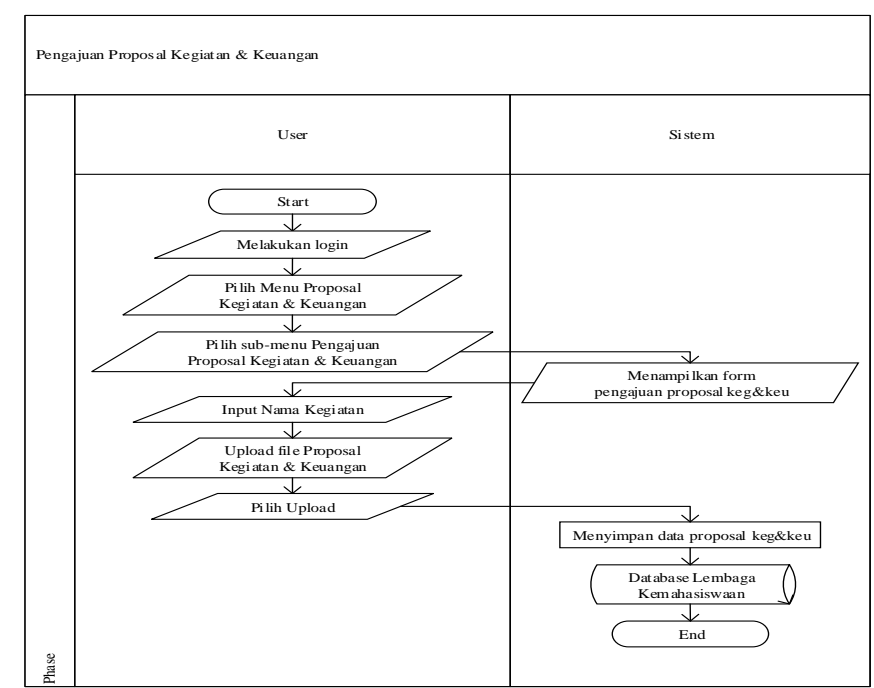

Gambar 5. Flowchart Pengajuan Proposal Kegiatan dan Keuangan

Gambar 5 menunjukan flowchart pengajuan proposal kegiatan dan keuangan, user login menggunakan username dan password untuk menuju ke halaman utama sistem. User terdiri dari panitia atau satgas. Menu ini digunakan user untuk upload file proposal kegiatan dan keuangan. 


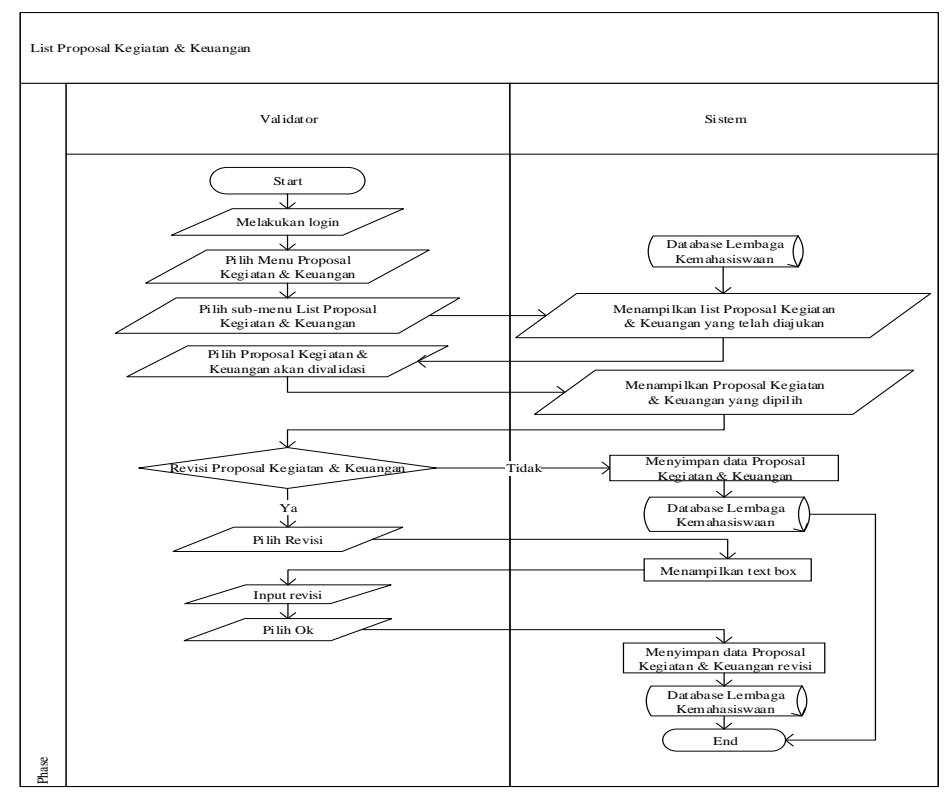

Gambar 6. Flowchart List Pengajuan Proposal Kegiatan \& Keuangan

Gambar 6 menunjukan flowchart list pengajuan proposal kegiatan dan keuangan, validator login menggunakan username dan password untuk menuju ke halaman utama. Validator terdiri dari fungsionaris LKF, fungsionaris LKU, Koorbidkem, Bikem dan PR III. Validator memiliki peran untuk memvalidasi proposal kegiatan dan keuangan yang telah diajukan.

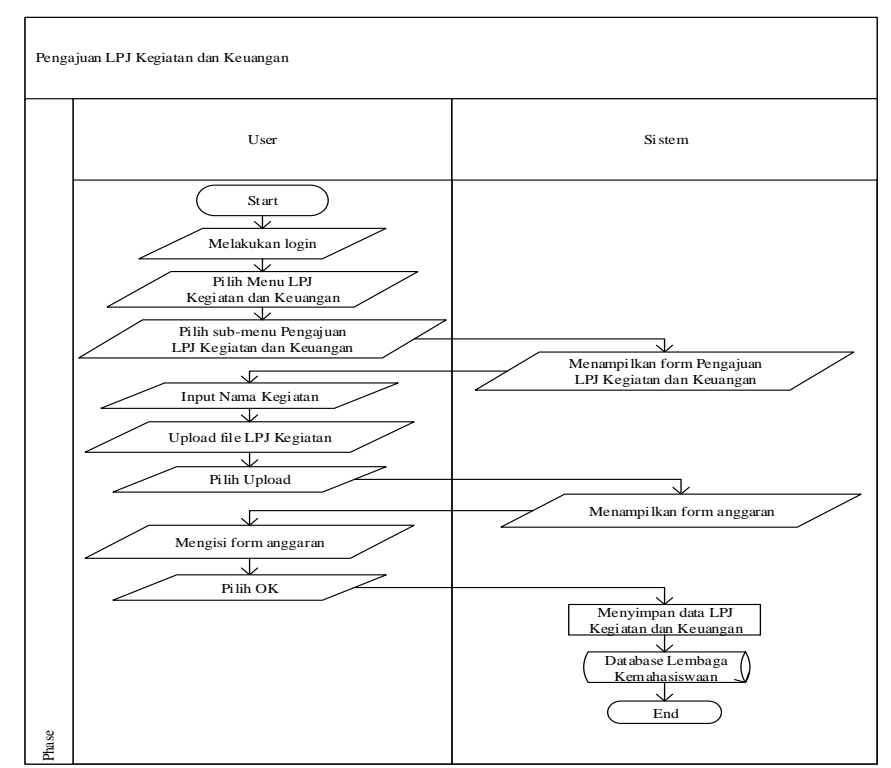

Gambar 7. Flowchart Pengajuan LPJ Kegiatan \& Anggaran

Gambar 7 menunjukan flowchart pengajuan LPJ kegiatan dan keuangan, user login menggunakan username dan password untuk menuju ke halaman utama sistem. User terdiri dari panitia atau satgas. Menu ini digunakan user untuk upload file LPJ kegiatan dan keuangan. 


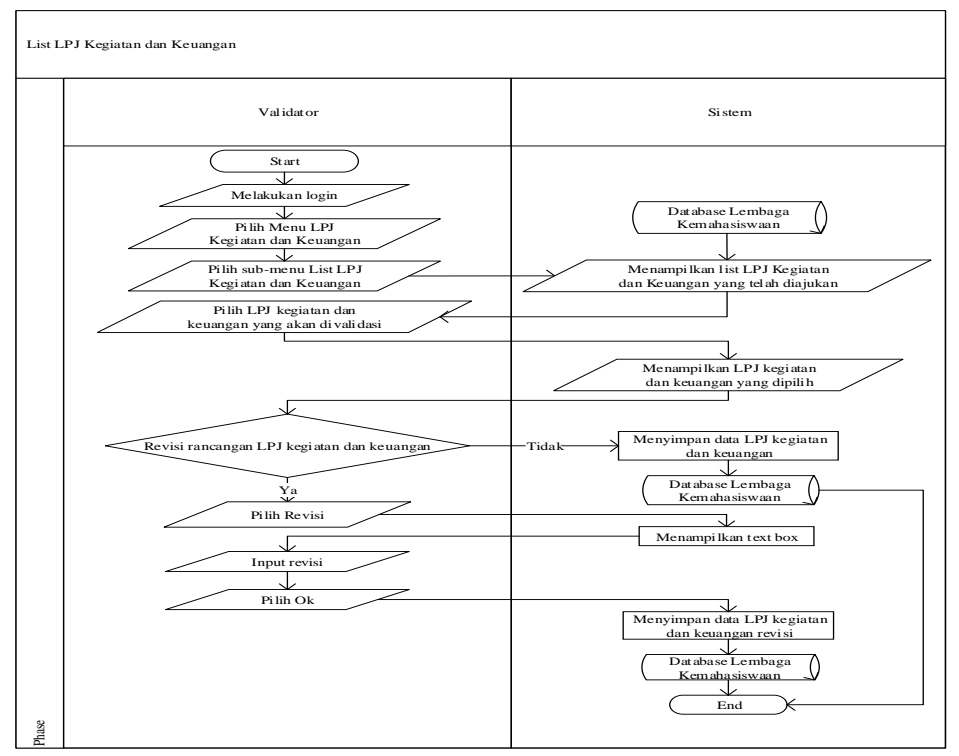

Gambar 8. Flowchart List Pengajuan LPJ Kegiatan \& Keuangan

Gambar 8 menunjukan flowchart list pengajuan LPJ kegiatan dan keuangan, validato terlebih login menggunakan username dan password untuk menuju ke halaman utama. Validator terdiri dari fungsionaris LKF, fungsionaris LKU, Koorbidkem, Bikem dan PR III. Validator memiliki peran untuk memvalidasi LPJ kegiatan dan keuangan yang telah diajukan. Koordinator Bikem mengatakan "alau kita berbasis datang, bawa proposal, koreksi kembali itukan takes time sebenarnya, tapi kalau ada sistem yang di desain sedemikian rupa sehingga alur data bisa paperless, kemudian kita bisa koreksi anytime, yang korespondensinya tidak harus datang kesini, itu dari sisi aksessibilitas. Dan yang penting adalah fungsi kontrol terhadap seluruh hasil kesepakatan teman-teman mahasiswa dalam rakor" (Giner Maslebu, wawancara, 9 Maret 2020).

Koordinator Bikem menjelaskan kondisi yang sedang berjalan bahwa proses pengecekan dan validasi dokumen menggunakan berkasi fisik dan dilakukan face to face. Oleh sebab itu sistem informasi SI LK dirancang untuk mewadahi proses pengecekan dokumen yang dapat dilakukan tanpa harus tatap muka. Pengecekan dokumen berdasarkan program kerja yang telah disepakati dalam rapat koordinasi bisa diakses dan dicari dengan mudah sesuai kebutuhan tanpa harus membolak-balikan tumpukan kertas

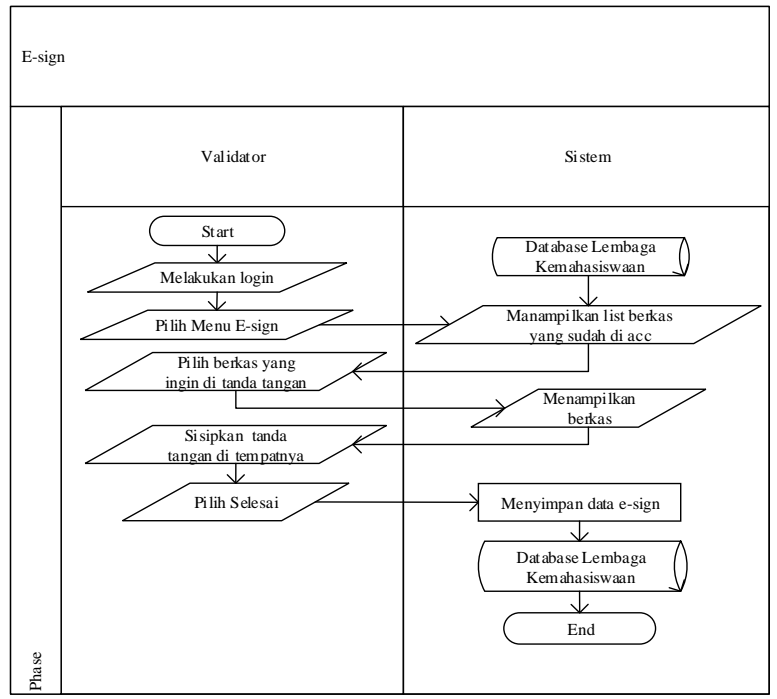

Gambar 9. E-signature

Gambar 9 menunjukan flowchart e-signature, validator login menggunakan username dan password untuk menuju ke halaman utama. Validator terdiri dari fungsionaris LKF, fungsionaris LKU, Koorbidkem, dan PR III. Validator memberikan e-signature sebagai output bahwa dokumen yang diajukan telah divalidasi. 


\subsection{Data Flow Diagram (DFD)}

Tahap selanjutnya merancang Data Flow Diagram (DFD) yaitu diagram yang menggunakan notasi berupa simbolsimbol untuk menggambarkan arus data pada suatu sistem [3]. DFD digambarkan mulai dari level 0, level 1 hingga level 2. DFD level 0 berada di tingkatan paling tinggi, yang menjelaskan satu lingkaran besar yang mewakili sistem yang berinteraksi dengan eksternal entitas Semua entitas yang ada pada DFD termasuk juga aliran datanya diarahkan langsung kepada sistem. DFD level 1 adalah semua proses dipecah menjadi sub-proses kemudian dirinci lebih lengkap dan detail. DFD Level 2 merupakan gambaran dengan penjelasan yang lebih lebih detail dari DFD level 1.

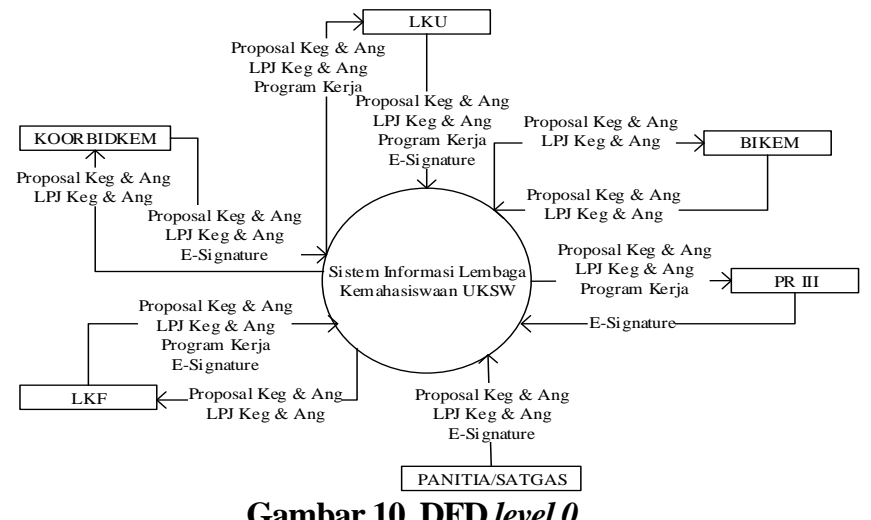

Gambar 10. DFD level 0

Gambarr 10 menunjukan DFD level 0, menggambarkan seluruh entitas berinteraksi dengan sistem. Di DFD menunjukan aliran data masuk dari enitas ke sistem dan aliran data keluar dari sistem menuju entitas.

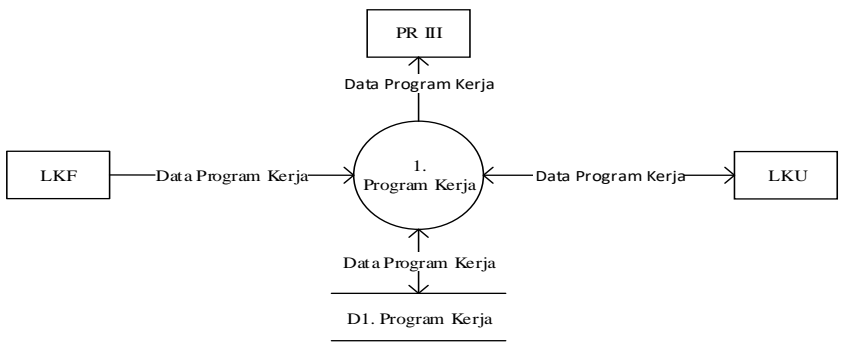

Gambar 11. DFD level 1 Program Kerja

Gambar 11 menunjukan data flow diagram program kerja, data program kerja diupload oleh fungsionaris LKF dan fungsionaris LKU. Data program kerja yang telah diupload oleh fungsionaris LKF akan divalidasi secara bertahap oleh fungsionaris LKU dan PR III. Data program kerja yang diupload oleh fungsionaris LKU akan divalidasi oleh PR III. Seluruh data program kerja akan disimpan dalam database program kerja.

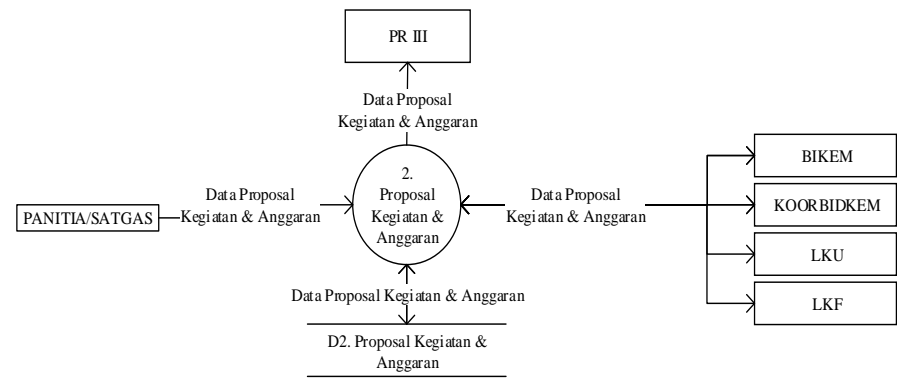

\section{Gambar 12. DFD level 1 Proposal Kegiatan dan Anggaran}

Gambar 12 menunjukan data flow diagram proposal kegiatan dan anggaran, data proposal kegiatan dan anggaran diupload oleh panitia atau satgas, fungsionaris LKF dan fungsionaris LKU. Data proposalkKegiatan dan anggaran yang telah diupload oleh panitia atau satgas akan divalidasi secara bertahap oleh fungsionaris LKF, koorbidkem, fungsionaris LKU, bikem dan PR III. Data proposal kegiatan dan anggaran yang telah diupload oleh fungsionaris LKF akan divalidasi secara bertahap oleh Koorbidkem, fungsionaris LKU, bikem dan PR III. Data proposal kegiatan dan anggaran yang telah 
diupload oleh LKU akan divalidasi secara bertahap oleh bikem dan PR III. Seluruh data proposal kegiatan dan anggaran akan disimpan dalam database proposal kegiatan dan anggaran.

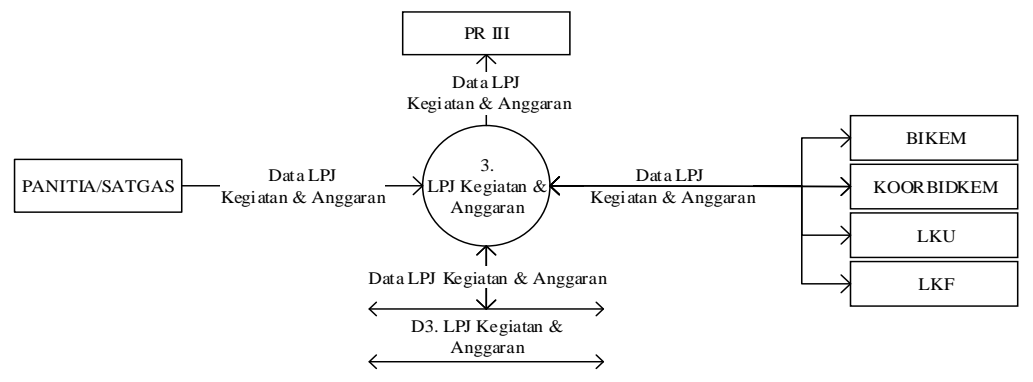

\section{Gambar 13. DFD level 1 LPJ Kegiatan \& Anggaran}

Gambar 13 menunjukan data flow diagram lpj kegiatan dan anggaran, data lpj kegiatan dan anggaran diupload oleh panitia atau satgas, fungsionaris LKF dan fungsionaris LKU. Data lpj kegiatan dan anggaran yang telah diupload oleh panitia atau satgas akan divalidasi secara bertahap oleh fungsionaris LKF, koorbidkem, fungsionarisLKU, bikem dan PR III. Data lpj kegiatan dan anggaran yang telah diupload oleh fungsionaris LKF akan divalidasi secara bertahap oleh koorbidkem, fungsionaris LKU, bikem dan PR III. Lpj kegiatan dan anggaran yang telah diupload oleh fungsionaris LKU akan divalidasi secara bertahap oleh bikem dan PR III. Seluruh data lpj kegiatan dan anggaran akan disimpan dalam databaselpj kegiatan dan anggaran.

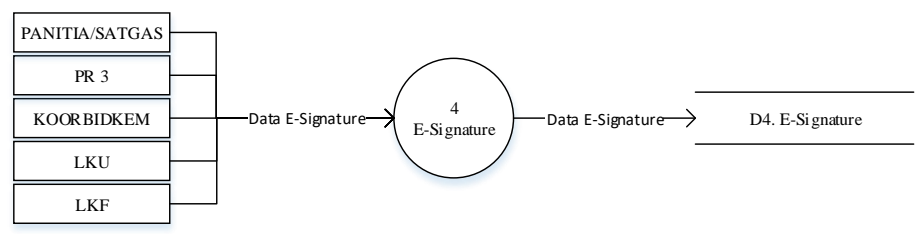

Gambar 14. DFD level 1 E-signature

Gambar 14 menunjukan data flow diagram pada e-signature, data e-signature diinputkan oleh pantia atau satgas, fungsionaris LKF, koorbidkem, LKU dan PR III. Data e-signature berupa tandatangan sebagai bukti dokumen telah divalidasi seperti program kerja, proposal, maupun lpj. Data e-signature akan disimpan dalam database e-signature.

\subsection{Entity Relationship Diagram (ERD)}

Entity Relationship Diagram (ERD) adalah pemodelan yang menggambarkan basis data secara relasional [4]. Dalam penelitian ini ERD merupakan model dalam mendesain database yang memiliki nilai data yang saling berelasi. 


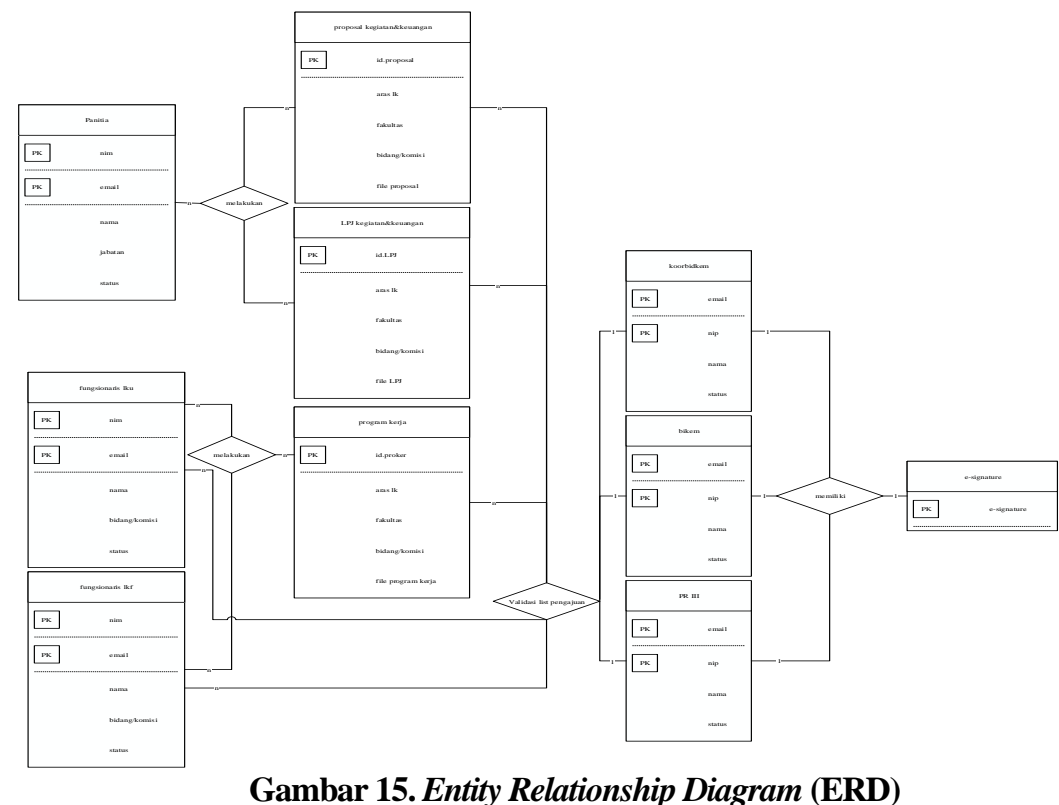

Gambar 15. Entity Relationship Diagram (ERD)

Gambar 15 menunjukan relasi, relasi adalah hubungan anatara entitas yang berbeda. Entitas dalam ERD ini adalah fungsionaris LKF, fungsionaris LKU, Koorbidkem, Bikem, PR III, pengajuan program kerja, pengajuan proposal kegiatan dan keuangan, pengajuan lpj kegiatan dan keuangan dan e-signature. Dalam mendesain database setiap entitas memiliki primary key yaitu atribut yang bernilai unik, contohnya entitas fungsionaris LKF dan fungsionari LKU yang memiliki nim dan email sebagai primary key, artinya nim dan email setiap fungsionaris tidak ada yang sama yang disebut bernilai unik. Setiap relasi memiliki kardinalitas yaitu, jumlah himpunan relasi antara entitas yang berbeda. Relasi antara panitia dan program kerja memiliki kardinalitas many to many artinya lebih dari satu panitia dapat mengajukan banyak program kerja.

\subsection{Tampilan Antar Muka}

Wireframe adalah panduan visual yang mewakili kerangka situs web [5]. Wireframe berfungsi untuk menghubungkan dari konseo konsep kemudian mempresentasikan ke bentuk tampilan. Dalam tahap pengembangan wireframe lebih berfokus pada fitur fungsional, bukan elemen visual. Warna yang banyak digunakan adalah hitam, putih dan abu-abu. Desain tampilan website dipilih karena website dianggap lebih mudah dikembangkan serta mudah diakses oleh berbagai devices dan sistem operasi. Berikut adalah desain tampilan website sistem informasi lembaga kemahasiswaan.

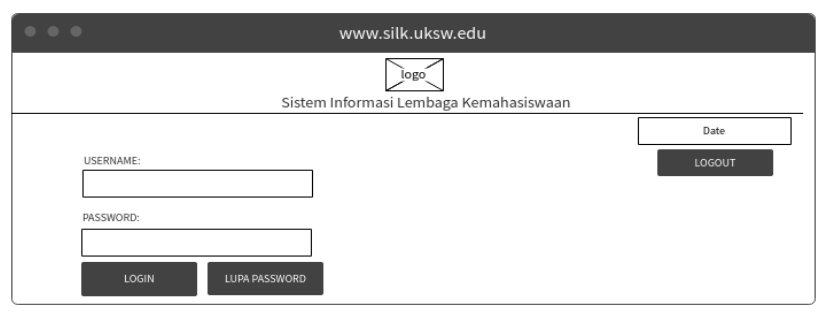

Gambar 16. Tampilan login

Gambar 16 menunjukan tampilan awal sistem. Login menggunakan username dan password kemudian pilih login, maka sistem masuk ke halaman utama. Halaman utama user berbeda-beda, hal ini tergantung pada previllage masingmasing user.

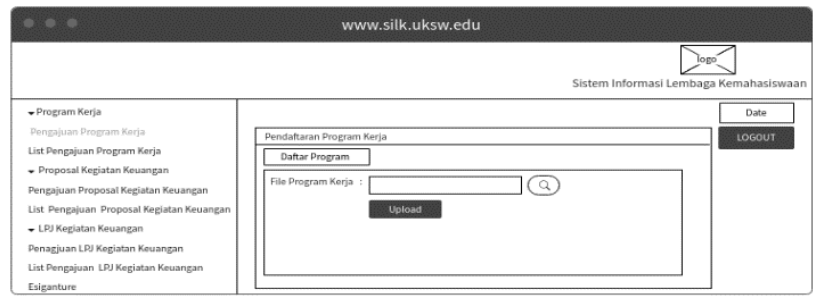

Gambar 17. Tampilan Pengajuan Program Kerja 
Gambar 17 di sisi kiri menunjukan tampilan awal sistem informai lembaga kemahasiswaan, terdapat 4 modul yaitu program kerja, proposal kegiatan dan anggaran, lpj kegiatan dan anggaran dan e-signature. Di tampilan awal sistem terdapat 8 menu yaitu, pengajuan program kerja, list pengajuan program kerja, pengajuan proposal kegiatan dan anggaran, list pengajuan proposal kegiatan dan anggaran, pengjuan lpj kegiatan dan anggaran, list pengajuan lpj kegiatan dan anggaran dan e-signature. Sedangkan di sisi kanan menunjukanf form pengajuan program kerja.

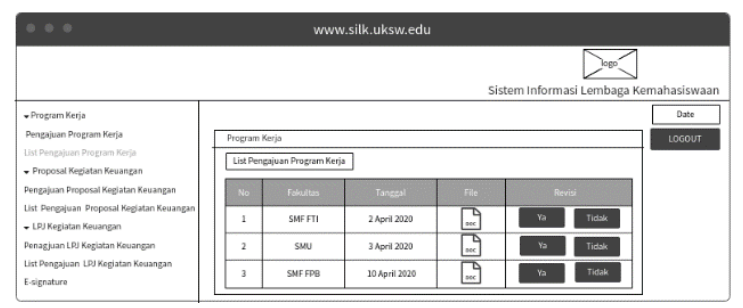

Gambar 18. Tampilan List Pengajuan Program Kerja

Gambar 18 menunjukan tampilan list pengajuan program kerja. Setelah upload program kerja, maka data akan masuk ke list pengajuan program kerja. Di menu ini validator melakukan pengecekan data. Kemudian melakukan validasi data, apakah data perlu direvisi atau tidak.

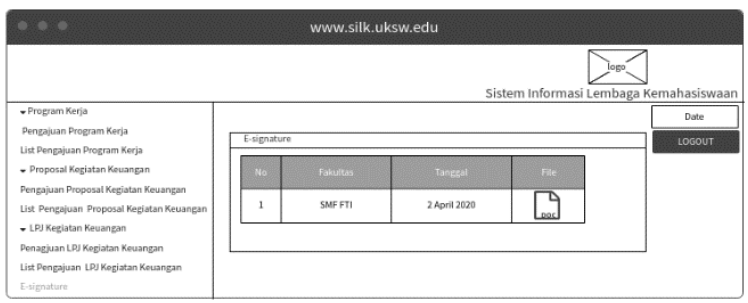

Gambar 19. Tampilan E-signature

Gambar 19 menunjukan tampilan e-signature. Setelah file melewati proses validasi, maka data akan masuk ke menu e-signature.

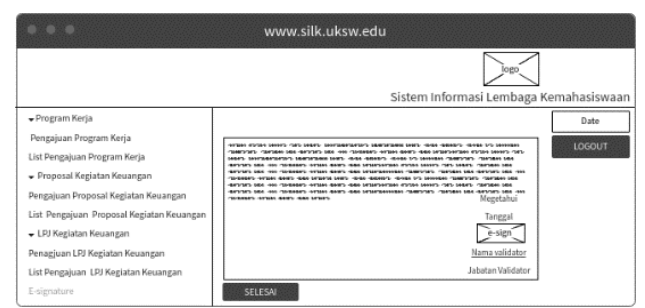

Gambar 20. Tampilan E-signature - Input e-signature

Gambar 20 menunjukan tampilan dokumen terpilih yang akan diinput e-signature oleh validator

\section{KESIMPULAN DAN SARAN}

\subsection{Kesimpulan}

Berdasarkan hasil penelitian dapat diambil kesimpulan yaitu sistem informasi lembaga kemahasiswaan UKSW dirancang sesuai kebutuhan pengguna berdasarkan hasil wawancara, kemudian sistem dirancang menggunakan flowchart untuk menggambarkan alur kerja sistem informasi, Data Flow Diagaram (DFD) untuk menggambarkan arus data yang ada di sistem informasi dan Entity Relationship Diagram (ERD) sebagai model untuk mendesain database. Tampilan antarmuka sistem lembaga kemahasiswaan dirancang mengunakan wireframe yang disesuaikan dengan tampilan website.

\subsection{Saran}

Saran pengembangan yang dapat diberikan untuk penelitian lebih lanjut adalah penelitian ini dibuat sebatas digunakan untuk mewadahi pengelolaan proses program kerja, proposal kegiatan dan keuangan, dan lpj kegiatan dan keuangan, untuk pengembangan lebih lanjut diharapkan mahasiswa juga dapat mengakses sistem informasi, sehingga mampu mewadahi seluruh proses yang berkaitan dengan mahasiswa. 


\section{DAFTAR PUSTAKA}

[1] Wamese, Yoga Marsal. 2018. "Sistem Informasi Event Pekan Kretivitas Mahasiswa (PKM) Di UIN Raden Fatah Palembang”. Universitas Islam Negeri Raden Patah. 1-3.

[2] Kristiani,Tika Kristiani, Halim Fathoni, Zuriati. 2018. “Aplikasi Pencatatan Partisipasi Kegiatan Lomba Mahasiswa Universitas XYZ Berbasis Web”. Politeknik Negeri Lampung. 1-2.

[3] Hartono, Jogiyanto. (2005). Analisis Dan Desain: Sistem Informasi Pendekatan Tersetruktur Teori Dan Praktik Aplikasi Bisnis. Yogyakarta: Andi Offset.

[4] A.S Rosa, M.Shalahuddin. (2004). Rekayasa Perangkat Lunak: Terstruktur dan Berorientasi Objek. Bandung: Informatika.

[5] Brown, Dan M. (2010). Communicating Design: Developing Web Site Documentation for Design and Planning. New Riders. 